UDC 130.2:248.1:316.46

LOMACHINSKA IRINA,

Borys Grinchenko Kyiv University (Kyiv, Ukraine)

e-mail: lomachinskairina@ukr.net, ORCID 0000-0003-2537-6322

KHRYPKOSVITLANA,

Borys Grinchenko Kyiv University (Kyiv, Ukraine)

e-mail: s.khrypko@kubg.edu.ua, ORCID0000-0001-9426-4549

IATSENKO GANNA,

National Shipbuilding University named after admiral Makarov (Mykolaiv, Ukraine)

e-mail: iats2601@gmail.com, ORCID 0000-0002-8675-5118

\title{
THE IDEOLOGICAL SOURCES OF RELIGIOUS LEADERSHIP IN UKRAINIAN CULTURAL SPACE
}

The urgency of a problem is determined by the strengthening influence of religious leadership on social and political processes in Ukrainian society. The religious leadership is predominantly considered in political context (as the juxtaposition of political leadership in forms and means of power access) and structural context (as being the main factor of a church structure establishment) in modern scientific thought. Among the theological thought representatives an idea of religious leadership is followed in a theological doctrine of ministry as spiritual mentorship. Simultaneously, an issue of spiritual and cultural activity of the Orthodox religious leadership has not been an object of active scientific study yet; hence a primary aim of the article is to determine the sources of a leadership's idea in national religious and cultural traditions. A sense of religious leadership as a sophisticated institutional structure was specified in the process of an issue analysis thus identified the development directions of national religious area as well as national social and cultural space. An article highlights that the Orthodox clergy, predominantly monkhood which combined an idea of ascetic feat with hectic social activity have formed Ukrainian archetypal image of religious leadership. The article proves that an idea of the Orthodox religious leadership has been formed on the patristic tradition basis and has been reflected in the following functions: an ideological function, a missionary function, a valued-based function, a ritual function, an integrational function. A religious leader always carries some religious ideology, expressed in a system of moral and social values; therefore he forms an ideal image that is the most relevant to a particular historical period. A religious leader's archetype is created in a sacral sphere, consequently, in contrast to a political leader; he is protected from radical ideological audits and saves the dominant influence on social consciousness.

Key words: the religious leadership; the Orthodox monasticism; the Orthodox monasteries; the national spiritual culture; the national spiritual values.

\section{Introduction}

The concept of the leadership has been reconsidered not only in political sphere, but also in religious context in the tough modern geopolitical circumstances and religious, cultural contradictions of Ukrainian society's existence. This leads to necessity of a concept historical sources analysis and peculiarities of national spirituality transformation study. The religious leaders due to their personal moral traits and individual mystical experience not only direct the society to a sacral transcendental aim achievement according to their powerful psychological and communicational characteristics, hence they have a profound influence on social and political processes of Ukrainian society.

Purpose of the research is to determine the origins of the leadership issue in the sphere of national religious and cultural tradition.

The issue of cultural and spiritual activity of the Orthodox religious leadership has not been an object of active scientific research yet. The presented issue diversity has subjected the inclusion to its analysis the Orthodox theological heritage, namely Vasil the Great, Gregory the Theologian, John Chrysostom, Theodore the Studite, philosophic and religious studies of S.Bulgakov, V. Horskyi, A.Kartashev, A.Nikolin, etc.

\section{Methods}

Methodology of the study is based on a dialectical relationship of the following methods: a comparativehistorical method is applied for historic peculiarities determination in national religious leadership establishment; a comparative analysis is used in a study of common and specific religious leadership determination at different stages of national history; a functional analysis is involved in a process of dynamic's features study of functional national religious leadership determination; a systematic analysis is traced in a religious leadership identification as a coherent system in various cultural implementations. 


\section{Research and results}

The national cultural space is determined by a dominant religious system of values in a particular historical epoch to a great extent and is cultivated by the religious leadership as a peculiar archetypical image which subjects the social spiritual necessity realization and the mora values system evolution of the human civilization. The national culture genesis is an integral part of a cult as its spiritual base that determines its sacral sense and valuebased meaning. According to P. Gurevich, "the cultural construction itself, its purpose cannot be considered without a hierarchy of the cult nature. Whatever are the explanations of culture and civilization connection, the religious leaders see that there are the deep fundamental bases of a culture precisely in religion" (Gurevich P., 1995: 110). Consequently, having possessed the personal charisma or charisma obtained via tradition or status, the religious leadership determines the process of values' changes in the society according to the position of the particular religious views.

Having compared the characteristics of a status of religious and political leaders, the following features can be highlighted. A religious leader, in contrast to a political one, does not claim the special power of the authorities, as his legitimacy has been determined in advance and charisma is beyond the doubts. Any fault of a religious leader is not his personal mistake; it becomes a part of a Divine providence, as a result it cannot be count as a leader's defeat. A religious leader has obtained the appropriate divine attributes; his authority is based on people's faith in the power of divine vocation, thus is implicit. The authority of a political leader is normally based on power, therefore for a legitimacy support of their rule they wish to have divine attributes inherent in religious leaders.

The peculiarities of Christian tradition adoption in a society of Kyivska Rus have determined the main functions of the Orthodox religious leadership in the national cultural space: a missionary and promotional function (the social worldview is built by Christian values spreading and the Orthodox church ideology approval), a political function (presents the influence on political processes' dynamics for the most optimal existence conditions creation of the religious institutions), an economic function (presents the ideological support of a church economic activity basis as a social institute), a cultural and educational function (presents the material and spiritual artefacts development), a moral function (presents the spiritual valued system statement via education, literature, art). The above-mentioned functions in the context of historical evolution were in close connection that ensured the Orthodox religious and cultural tradition dissemination as a dominant one.

The domestic Orthodox religious leadership system inherited significantly from Byzantine tradition, as Byzantine Empire transferred along with the Eastern Orthodox ceremony to Rus its system of state and church authority relationships. As A. Nikolin suggests, "A profound role has played Byzantium tradition in the process of Rus awareness of the two services necessity - a monk embodies the primary source of religious purification and a warrior presents the primary source of state coercion" (Nikolin A., 1997: 2).

The philosophical bases of harmonious relationships building between church and state in the period of Kyivska Rus are provided in the famous "The Treatise on the Law and Grace" by metropolitan Illarion: all nations are equal before God - "such principle was opposite to Byzantium claim to be the first one in the Christian world (a spiritual personality formed on such base for whom any chauvinism and racism was alien and unnatural); state and church functions are to be divided: the secular authority should care about secular national activities, however the church, shepherd authority should care about goodness of souls, be responsible for moral state of a nation" (History of the Orthodox Church in Ukraine, 1997: 294). Thus, there is a clear division of the spiritual and political leaders' zones of influence.

The peculiarity of Christian doctrine's legitimacy in the social consciousness was conditional upon the simultaneous development of secular and church authorities in Kyivska Rus, consequently they were interpreted as an interconnected phenomenon in common Rusich consciousness. Therefore, the political leaders' activity was accepted through the light of their support (or possible opposition) of the Orthodox Church activity in different spheres, namely through mission activity, church building or monastic practice. As a result, the religious leaders played a secondary role in general evaluation of the activity measurement of the political leaders' Christian practice.

Having analyzed abovementioned, the issue about common and distinction features of state and church institutions in hierarchical social authority relations and the abilities of authority's realization has arisen. A state and church have the common features according their building; a church is composed from hierarchical communities, and hierarchy itself is a church body's skeleton. As $\mathrm{S}$. Bulgakov mentions hierarchy is "a unified charismatic service in a church which has a general meaning and its existence resumes the lack of supernatural charismatic character, however it does not exclude it. What does a hierarchy in the Christian church mean? Firstly, it is power to perform religious rites, as it carries the mysterious superhuman and supernatural power" (Bulgakov S., 1991: 51).

A church subordination to the authorities posed a problem of the authorities' sacral nature. Despite of the peaceful and painless character of Christianity adoption in Rus, a new faith was not able to eliminate paganism in medieval ancient Russian consciousness which disappeared in the range of mythological beliefs. Therefore, we could approve that on a stage of Christian doctrine adoption the urgent problem was a necessity of sacral acts performance under the charismatic political leaders who not only contributed to Christian values adoption in a society, but also became the spiritual leaders of their nation.

The political context of the Orthodox faith inculcation as a state religion by prince Volodymyr formed the conditions for Byzantium tradition of a sacral leader's nature succession. The princess Olga and prince Volodymyr in the pantheon of ancient Russian saints are distinguished by a performed apostolic mission that according to a church view is evaluated higher than a heroic deed of martyrdom or deeds of confessions which the other historical persons from the cohort of ancient Russian saints are famous for. This fact highlights the dominant apostolic focus of the religious leadership for all Christian tradition. Prince Volodymyr's image (as Princess Olga's image) in hagiographical literature is created on the contrast between their pagan and Christian life, a composed ideal of a Christian wise man-hermit is contrary to a pagan warrior. That fact influenced on Christian basis of a national leadership system development.

Christianity had built a new moral imperative due to which as V. Horskyi mentioned "the inherent Biblical religious tradition view on a person as a creature who had been growing, the essence of whom had been implemented, but not already performed. That fact was meaningful not only for yesterday's pagans; admittedly it determined a line of behavior of a newly-converted Christian... The maximally widest amplitude from absolute evil to the highest goodness highlighted the way of life that

SKHID No. 3 (161) May-June 2019 
had been passed by Volodymyr and particularly by Olga; it was to demonstrate vividly the grace of human's will that could ascend to the highest levels of sanctity from the very bottom" (Horskyi V., 2001: 86-87).

In the figures of Olga and Volodymyr the traditional and charismatic rule connection, with the clear dominance of the last one, is implemented that gives an opportunity to develop their leadership's potential, on the other hand the sacral rule excludes any revision attempts of new religious worldview given as a national faith in the future. The crucial factor of a religious leader's image construction is numerous hagiographical literature that creates the most desirable image of a religious leader which has timeless sense. The source of hagiographical literature appearance is Apostol Paul's words "Remember your former leaders, who spoke God's message to you" (Heb. 13: 7). The specific feature of Christian consciousness is that an individual way of salvation is considered as a single part of a collective way prescribed by hagiographical literature; as a result any particular person is eliminated in it, however common personal characteristics are included into a collected image of a saint.

The national religious and cultural tradition of "saint devotees of Church" determines the following categories: equal to the Apostles, sanctifiers, martyrs, reverends, and righteous seculars. Consequently, the Orthodox idea of leadership is not limited by a religious sphere, as righteous seculars are included to a galaxy of Church devotees.

The ideological basis of the Orthodox idea of leadership development is established in an early Christian conception of shepherd activity proved by the works of Vasil the Great, Gregory of Nissa, Gregory the Theologian, John Chrysostom, John Climacus, etc. According to Gregory's the Theologian theory the necessity for priesthood derives from a Church's hierarchical structure that is a body connected with the Head - Jesus Christ. Such idea related to Apostol Paul's issue inspires Gregory to the reflections on order as a base of all essence of a church. Hierarchy saves a church from anarchy, the existence of priesthood and episcopacy ensures a church unity like in an organism where each part carries its function: "one part rules, another obeys, as in church God has established (according to a law or justice, or providence) that ones, for whom it is useful, are coordinated to their duties by a word and deed, therefore they should stay to be directed, the others who are on a higher level due to their virtuous and closeness to God should be shepherds and teachers" (Gregory the Theologian).

Owing to John's Chrysostom claim, priests are "the givers of our birth in God, blessed revival, the real freedom and beneficial adoption" (John Chrysostom, 2001: 92). The tradition of shepherd's activity facilitated the national spiritual ascetic ideals dissemination.

Monasticism with its direction on an internal ascetic feat became an opportunity to reach an ideal of Christian way of life in the Orthodox religious and cultural tradition, furthermore freedom from secular duties was not only an example of purity, it created the possibilities of unhindered missionary activity.

The religious leadership of monkhood occupied a special part in the Orthodox pantheon of saints, as owing to the moral choice determined by hermit life and corporal asceticism was an example for a spiritual social succession. Monasticism became a testimony of height and sanctity of Gospel doctrine, visible embodiment of Christian and ethnical concepts, prediction of future world transformation in general and a specific human change in particular. It was inspired by the high ethnical Christian faith ideals in the process of its development, which became the forthcoming milestones. A monk position in the Orthodox consciousness empowers a person with the moral virtues and allocates him from the secular environment.

A prominent organizer of monastic life and a father of Malaysian monasticism supposed to be Vasil the Great, who became an author of monastic community's statute and a persistent preacher of cenobitical community's ideal where "no one should be a self-owner, however everyone, who was sent to brotherhood service by God, had to perform everything according to his rank" (Vasil the Great, 2007: 71). His views were supported by Theodore the Studite.

It should be mentioned that at the beginning of Christian belief adoption in Rus, priesthood usually consisted of monastic clergy, nevertheless the further monasteries' division on Keliotic monasteries (were on maintenance of their founders - ktitors) and Pachomian monasteries (independent monastic communities that existed on the base of self-government) led to the church authority establishment with the dominance of monastic clergy. As A. Kartashev highlighted (Kartashev A., 2009: 239) in contrast to the monastic communities of Keliotic monasteries that mostly consisted of the Greeks and noble ancient Russians, Pachomian monastic communities formed from the representatives of all social layers and were more popular.

The Pachomian monasteries in the system of medieval feudal society developed as a religious community associated with common religious and cultural experience, traditions, material interests, norms of behavior, spiritual values and clear organizational structure. An example of further growth of such monastic communities was Kyiv Pechersk monastery where Feodosiy Pechersky skillfully connected moral bases of Theodore's the Studite monastic statute with an ascetic practice of economic activity. An idea of service was formed by Theodore the Studite: "Everyone should perform his service and implement a gift accepted from God in favor of brotherhood" (Theodore the Studite, 1999: 66). That thought was realized into a distinctive process of labor activities' sacralization, physical labor determination as a necessary connection of physical and spiritual feat on the way of "flesh sacrifice" and "spirit resurrection".

Monasticism did not become a line which crossing meant a total break with a secular world in the ancient Russian social consciousness. A total transformation of a primary monastery's sense as "a place of solitude" occurred under the influence of historic circumstances (the monastic communities were placed near cities), national mentality (a tradition of monasteries' building as "family tomb" was initiated by Kyiv Princes).

Owing to the active charity, monasteries emerged as active social institutes that facilitated the monastic clerical profound influence on political and cultural processes.

M. Gorchakov mentioned that "a church established a principle: "church wealth was wealth of the poor" in order to avoid any contradictions between rich possessions and ascetic life style. A head of a monastery had to spend a minimum income share on monastic clergy; hence the rest income part was to be invested into church building, school teaching and charity due to the introduced principle" (Gorchakov M., 1909: 50).

Kyiv Russian monkhood were carriers of new Christian ideology based on centuries-old Byzantium spiritual and ethical experience of religious, cultural traditions, consequently a necessity of missionary activity forced active influence on Russian pagan consciousness. The specified active social process of ideological pressure created by monasteries, excluded their division of social and cultural environment. The main means of ideological influence became not only preaching activity, but also 
educational, religious and art work (painting, architecture, decorative and applied arts).

For instance, the sacral meaning of cult monastic architecture embodied into the first "Word" by "Kyiv Pechersk Patericon" (Kyiv Pechersk Patericon, 1991: 1-5), where The Cathedral of the Assumption building derived from God's Providence. Therefore, the main cathedral of a monastery became a sacral center which shaped monastery's space, a monastery itself was considered as a center for Kyivska Rus.

Cult and liturgical activity of the Orthodox monasteries formed a new phase in ancient Russian foreign trade development, as for Christianity spreading a metropolis of Kyiv needed large amount of cult objects which could be brought particularly from Byzantium.

Regarding to education and literature, schools existed only in Keliotic monasteries, were oriented on princes' children teaching and supported by the rich ktitors in the period of Kyivska Rus. Books were rewritten in monastic scriptoriums for noble families. Libraries existed mainly in cenobitical monasteries, their creation had most likely not educational, but financial aim, as books presented the only valuable thing which a monk could have in a monastery (according to the Studite monastic statute). Therefore, having taken the monastic vows, the representatives of noble families transferred their property into books that became monastic libraries' heritage. Later, "special attitude to books as to the great treasures... was transmitted to the next generations of monastic inhabitants. It enabled to save the precious treasures of national culture for the future generations" (Lomachinska I., 2015: 9).

The crucial meaning for national spiritual culture belongs to decisive influence of the national Orthodox priesthood on the national history's maintaining and reconstruction process. National memory's maintaining was based on ancestor-worship practices' substitution by Christian burial ceremonies and large developments of monastic necropolis. Moreover, tradition of chronicles keeping was a fundament of Ukrainian national history preservation.

A system of the religious leadership has always built on a "challenge-answer" principle. A principle mission of the religious leadership is to establish ideological basis for further social transformations, therefore the main aim is to obtain an ability to accept historical challenges and adequately react on them. Consequently, the stages of the national and cultural Orthodox monasteries' activity growth were closely connected with the historical demands, namely at the period of relative political and ideological stability their cultural activity was restricted by religious sphere, nevertheless at the time of tough ideological conflicts the revitalization of social and cultural activity could be noticed.

The social Orthodox monkhood's activity was conditional upon a necessity of Cristian ideology propaganda and church establishment as a social institute at the period of Kyivska Rus. The political monasteries' support could have a temporary character under the absence of a clear authority's system and in conditions of internecine wars. However, active agricultural activity accompanied by generous donations of influenced benefactors was fruitful ground for political independence and national cultural basis establishment.

In the period of Mongol-Tatar invasion, under the circumstances of absence of religious discrimination the Orthodox monasteries were inactive in cultural and educational spheres. The possibilities of their survival in economic crisis were created by agricultural orientation.

In the period of Polish-Lithuanian rule a break with
Byzantium tradition led to weakening of national monkhood's ideological basis, gradual loss of the leading positions in social Ukrainian worldview formation. The result was the gradual Catholic expansion.

\section{Results and Discussions}

Having analyzed the issue, a sense of religious leadership as a complicated organizational structure has been designated which extremely determined religious areas as well as social and national cultural space. Due to the historical circumstances the Orthodox clergy, predominately monkhood, who connected an ascetic feat idea with social activity had profound influence on social consciousness and formed an archetypical image of religious leadership. The image has preserved its relevance in religious and political spheres as well as in social and cultural space.

\section{Conclusions}

In Ukrainian religious and cultural tradition an idea of the Orthodox religious leadership was built on the basis of patristic tradition and reflected into the following functions: an ideological function, which is aimed to establish Christian faith ideology; an organizational function, which is focused on the church organizational structure establishment; a missionary function which is intended to Christian faith dissemination; a valued-based function, which is intended to Christian system of moral and ethical values development and implementation in a religious community; a ritual function, which is based on cult ceremonies support; an international function, which is expressed in cooperation with other social institutes. On the stage of Christian doctrine adoption the crucial necessity was to begin a process of charismatic political leaders sacralization contributed to Christian values adoption in a society and became spiritual leaders for their nation respectively. A religious leader always carries some religious ideology, expressed in a system of moral and social values; therefore he forms an ideal image that is the most relevant to a particular historical period. A religious leader's archetype is created in a sacral sphere, consequently, in contrast to a political leader; he is protected from radical ideological audits and saves the dominant influence on social consciousness. Considering diversity of a given issue, we are able to stress the necessity of further scientific study in historical context as well as in modern aspect, namely in political sphere (as power sacralization evokes a social danger to modern political life); in economic sphere (as the necessity to form a church social doctrine under global challenges); in social and cultural spheres (as a mean of a national church idea spreading, which is oriented on the main basis of national spirituality revival).

\section{REFERENCES}

Bulgakov, S. N. (1991). Pravoslaviye. Ocherki ucheniya pravoslavnoy tserkvi. Kyiv: Lybid, 238 p. (In Russian)

Basil of Caesarea (Saint Basil the Great) (2007). Primite slovo moye: Sb. pisem. Moscow: Izd. Sretenskogo monastyirya, 384 p. (In Russian)

Horskyi, V. (2001). Filosofiya v ukrayinskiy kulturi (metodolohiya ta istoriya): Filosofski narysy. Kyiv: Tsentr praktychnoi filosofii, 236 p. (In Ukrainian)

Gorchakov, M. I. (1909). Tserkovnoye pravo. St. Petersburg: Typ.Hranshelia, 338 p. (In Russian)

Gregory the Theologian, The word defensive when fleeing to Pont. Retrieved from https://azbyka.ru/otechnik/Grigorij_Bogoslov/ slovo/3 (Accessed: 20.04.2019) (In Russian)

Gurevich, P. S. (1995). Filosofiya kultury. Moscow: Aspect Press. 288 p. (In Russian)

Istoriya pravoslavnoyi tserkvy $v$ Ukrayini (1997). Coll. sciences works. Kyiv: Chetverta khvylia, 292 p. (In Ukrainian)

SKHID No. 3 (161) May-June 2019 
John, Chrysostom (2001). Pro svyashchenstvo. Lviv: Monastyr Monakhiv Studytskoho Ustavu. Vydavnychyi viddil "Svichado", 156 p. (In Ukrainian)

Kartashev, A. V. (2009). Ocherki po istorii russkoy tserkvi. Vol.1. Moscow: Izd. Sretenskogo monastyrya, 784 p. (In Russian) Kyiv Pechersk Patericon (1991). Kyiv: Chas, 278 p. (In Ukrainian)

Lomachinska, I. M. (2015). Monastyri Ukrayiny. Kyiv: BaltiiaDruk, 208 p. (In Ukrainian)

Lomachinska, I. M. (2008). Relihiyne liderstvo v dukhovnomu vymiri khrystyyanskoyi tradytsiyi. Kyiv: University "Ukraina", 208 p. (In Ukrainian)

Nikolin, A. (1997). Tserkov i gosudarstvo: istoriya pravovykh otnosheniy. Moscow: Izd. Sretenskogo monastyrya, 430 p. (In Russian)

Ohiienko, I. I. (2002). Ukrayinske monashestvo. Kyiv: Nasha kultura i nauka, 396 p. (In Ukrainian)

Theodore the Studite (1999). Pouchennya. Lviv: Monastyr Monakhiv Studytskoho Ustavu, 226 p. (In Ukrainian)

\section{LIST OF REFERENCE LINKS}

Булгаков С. Н. Православие. Очерки учения православной церкви. Киев: "Лыбидь", 1991. 238 с

Василий Великий. Примите слово мое: Сб. писем. Москва: Изд. Сретенского монастыря, 2007. 384 с.

Горський В. Філософія в українській культурі (методологія та історія): Філософські нариси. Київ: Центр практичної фрілоcoфiï, 2001. 236 c.
Горчаков М. И. Церковное право. Санкт Петербург: Тип. Граншеля, 1909. 338 с.

Григорий Богослов. Слово защитительное при бегстве в Понт. URL: https://azbyka.ru/otechnik/Grigorij_Bogoslov/slovo/3 (дата звернення: 20.04.2019)

Гуревич П. С. Философия культуры. Москва: Аспект Пресс, 1995. 288 с.

Історія православної церкви в Україні: 3б. наук. праць. Київ: Четверта хвиля, 1997. 292 с.

Йоан Золотоустий. Про священство. Львів: Монастир Монахів Студитського Уставу. Видавничий відділ "Свічадо", 2001. 156 с.

Карташев А. В. Очерки по истории русской церкви. Т.1. Москва: Изд.-во Стетенского монастыря, 2009. 784 с.

Києво-Печерський патерик. Київ: Час, 1991. 278 с.

Ломачинська І. М. Монастирі України. Київ: Балтія-Друк, 2015. 208 c

Ломачинська І. М. Релігійне лідерство в духовному вимірі християнської традиції: монографія. Київ: Університет "Україна", 2008. 286 с.

Николин А. Церковь и государство: история правовых отношений. Москва: Изд. Сретенского монастыря, 1997. 430 с.

Огієнко І. І. Українське монашество / Упоряд., авт. іст.біогр. нарису та приміт. М. С. Тимошик. Київ. Наша культура і наука, 2002. 396 с.

Теодор Студит. Поучення [Г. Теодорович (пер.)]. Львів: Монастир Монахів Студитського Уставу, 1999. 226 с.

\section{Ломачинська Ірина,}

Київський університет імені Бориса Грінченка (м. Київ, Украӥна) e-mail: lomachinskairina@ukr.net, ORCID 0000-0003-2537-6322

\section{Хрипко Світлана,}

Київський університет імені Бориса Грінченка (м. Київ, Украӥна)

e-mail: s.khrypko@kubg.edu.ua, ORCID 0000-0001-9426-4549

\section{Яценко Ганна,}

Національний університет кораблебудування імені адмірала Макарова (м. Миколаїв, Украӥна)

e-mail: iats2601@gmail.com,ORCID0000-0002-8675-5118

\section{ВИТОКИ ІДЕЇ РЕЛІГІЙНОГО ЛІДЕРСТВА У ПРОСТОРІ УКРАЇНСЬКОЇ КУЛЬТУРИ}

Актуальність проблеми зумовлюється посиленням впливу релігійного лідерства на суспільно-політичні процеси українського суспільства. У сучасній науковій думці релігійне лідерство розглядалося, переважно, у політичному (як протиставлення лідерству політичному у формах і засобах досягнення влади) та організаційному (як основний чинник формування організаційної структури церкви) контекстах. У представників богословської думки ідея релігійного лідерства простежується у теологічній доктрині пастирства як духовного наставництва. Водночас, проблема духовно-культурної спрямованості діяльності православного релігійного лідерства поки що не стала об'єктом активних наукових досліджень, тому метою статті є визначення витоків ідеї лідерства у просторі вітчизняної релігійно-культурної традиції. У процесі аналізу проблеми була визначена сутність релігійного лідерства як складної організаційної структури, що значною мірою визначала напрями розвитку не лише релігійного, але й соціально-культурного вітчизняного простору. У статті підкреслюється, що православне священство, переважно чернецтво, яке поєднувало в собі як ідеї аскетичного подвижництва, так і активну соціальну діяльність, сформувало архетипічний образ українського релігійного лідерства. У статті доведено, що в українській релігійно-культурній традиції ідея православного релігійного лідерства формувалась на засадах патристичної традиції і відобразилась у наступних його функціях: ідеологічна, місійно-пропагандистська, ціннісно-орієнтаційна, літургійно-богослужбова, інтегративна. Релігійний лідер завжди виступає як знак певної релігійної ідеології, певної системи моральних та суспільних цінностей, тому він формує певний ідеальний образ, що є найбільш актуальним для конкретної історичної доби. Архетип релігійного лідера формується у зоні сакрального, тому, на відміну від лідерства політичного, він захищений від радикальних ідеологічних ревізій, та забезпечує домінуючий вплив на суспільну свідомість.

Ключові слова: релігійне лідерство; православне чернецтво; православні монастирі; національна духовна культура; національні духовні цінності.

(c) Lomachinska Irina, Khrypko Svitlana, latsenko Ganna

Надійшла до редакції: 26.04.2019

Прийнята до друку: 09.06.2019

СХІД № 3 (161) травень-червень 2019 р. 